\title{
KOMUNIKASI LINTAS GENERASI PADA MASYARAKAT TRADISIONAL SUNDA: KASUS MASYARAKAT KAMPUNG NAGA
}

\author{
Iwan Hermawan \\ Balai Arkeologi Bandung \\ Jl. Raya Cinunuk Km. 17 Cileunyi Bandung 40623 Telp. (022) 7801665, Fax. (022) 7803623 \\ e-mail: iwan1772@yahoo.com, HP: 0811204704 \\ Naskah dikirim pada tanggal 9 Oktober 2012, disetujui tanggal 21 November 2012
}

\section{CROSS-GENERATION COMMUNICATIONS IN SUNDA TRADITIONAL COMMUNITY: THE CASE OF NAGA VILLAGE}

\begin{abstract}
The generational communication across occurs in the social and community relations process. This process is necessary in order to develop positive values in society. The positive values will be passed down to the next generation so they can be a good life. The focus in this paper is a form of generational communication across that occurs in traditional Sundanese people. To answer the problems, this study used descriptive research methods with a qualitative approach. Data was collected through observation, description and interview. The results showed that the generational communication across takes place in the society of Naga village. The form of inheritance is pamali, habituation, and conditioning on the local environment.
\end{abstract}

Keywords: kampung naga society, values inheritance, cross generation communication.

\begin{abstract}
Abstrak
Komunikasi lintas generasi terjadi pada proses hubungan sosial dan bermasyarakat. Proses ini diperlukan agar nilai-nilai positif yang berkembang di tengah masyarakat dapat diwariskan kepada generasi berikut sehingga mereka dapat menjalani kehidupan sesuai dengan tata nilai yang berlaku pada masyarakat tersebut. Fokus permasalahan pada tulisan ini adalah bentuk komunikasi lintas generasi yang terjadi pada masyarakat tradisional Sunda. Untuk menjawab permasalahan yang diajukan, pada penelitian ini digunakan metode penelitian deskriptif dengan pendekatan kualitatif. Pengumpulan data dilakukan dengan cara observasi, deskripsi, dan wawancara. Hasil penelitian menunjukkan bahwa komunikasi lintas generasi berlangsung pada kelompok masyarakat Kampung Naga. Bentuk pewarisan tersebut adalah penjayaan pamali, pembiasaan, dan pengondisian masyarakat pada lingkungan setempat.
\end{abstract}

Kata Kunci: masyarakat kampung naga, pewarisan nilai, komunikasi lintas generasi. 


\section{PENDAHULUAN}

Kontak kebudayaan dari generasi terdahulu kepada generasi berikutnya merupakan sesuatu yang lumrah terjadi pada proses hubungan sosial dan bermasyarakat. Proses ini diperlukan sebagai bentuk pewarisan nilai kepada generasi muda, agar mereka mempunyai dasar kuat tentang nilai budayanya ketika terjadi kontak dengan kebudayaan lain. Tujuan komunikasi tersebut agar generasi muda dapat mempertahankan nilai-nilai positif yang telah menjadi pegangan generasi sebelumnya. Hal ini dikarenakan melalui komunikasi yang dilakukan individu secara berkelanjutan akan memengaruhi orang lain, bahkan memengaruhi masyarakat.

Pada masyarakat Sunda, proses komunikasi antara generasi tua dengan generasi muda dilakukan tiap individu, baik sebagai individu maupun sebagai bagian kelompok. Nilai baik-buruk atau benar-salah disampaikan kepada generasi muda dalam bahasa yang sama oleh setiap individu dalam kelompok sehingga pada prosesnya tidak terdapat multitafsir yang dapat menimbulkan perbedaan pemahaman. Proses pewarisan nilai pada kelompok masyarakat adat di tatar Sunda, seperti masyarakat Baduy, masyarakat Kampung Naga, masyarakat Kampung Mahmud, masyarakat Kampung Kuta, dan masyarakat Kasepuhan - Kaolotan dilakukan secara turun temurun.

Aktivitas interaksi sosial dan tindakan komunikasi tersebut dilakukan baik secara verbal, non verbal, maupun simbolis. Kebutuhan akan adanya sebuah sinergi fungsional dan akselerasi positif dalam melakukan pemenuhan kebutuhan manusia satu dengan yang lainnya ini kemudian melahirkan kebutuhan tentang adanya normanorma dan nilai-nilai sosial yang mampu mengatur tindakan manusia dalam memenuhi berbagai kebutuhannya, sehingga tercipta keseimbangan sosial (social equilibrium) antara hak dan kewajiban dalam pemenuhan kebutuhan manusia, terutama juga kondisi keseimbangan itu akan menciptakan tatanan sosial (social order) dalam proses kehidupan masyarakat saat ini dan waktu yang akan datang.

Salah satu media yang digunakan dalam komunikasi antara orang tua dan pimpinan adat dengan generasi muda atau anak-anaknya dilakukan melalui penjayaanpenjayaan pamali, buyut, atau tabu dalam kehidupan sehari-hari. Proses ini dilakukan guna mewariskan nilai-nilai positif dan mencegah mereka agar tidak berbuat kesalahan dalam kehidupan sehari-hari.

Pada masyarakat tradisional, termasuk masyarakat Kampung Naga, respon terhadap alam masih dilakukan dalam kehidupan sehari-hari. Mereka memuliakan dan menghargai alam yang diperlihatkan dalam keseharian ketika memanfaatkan alam. Menjaga alam dari kerusakan dilakukan oleh masyarakat melalui berbagai pamali atau pantang larang.

Kesederhanaan dalam hidup diajarkan kepada generasi muda dalam bentuk pandangan hidup, yaitu "hirup mah kudu tungkul ka jukut, tanggah ka sadapan" (menunduk harus ke rumput, menengadah harus ke tempat menyadap) yang artinya dalam hidup kita harus melihat kenyataan, tidak iri dengki terhadap kemajuan atau keberhasilan yang dicapai orang lain. Melalui ajaran ini diharapkan mereka bisa menerima apa yang menjadi rezekinya, dan tidak bernafsu untuk memiliki sesuatu yang bukan menjadi miliknya, termasuk upaya merusak alam hanya demi keuntungan sesaat karena alam adalah titipan yang harus disampaikan kepada anak cucu kelak di kemudian hari.

Proses pewarisan nilai pada kelompok masyarakat adat di tatar Sunda, seperti masyarakat Baduy, masyarakat Kampung Naga, masyarakat Kampung Mahmud, masyarakat Kampung Kuta, dan masyarakat Kasepuhan - Kaolotan dilakukan secara turun temurun, yaitu melalui tradisi lisan dan proses pembiasaan melalui penjayaan pamali atau pantang larang dalam kehidupan sehari-hari. Buyut menebang pohon di leuweung kolot (hutan tua), memanfaatkan lahan hutan untuk pertanian, mempergunakan pupuk buatan dan obat-obatan pertanian, mempergunakan detergen dalam kehidupan sehari-hari, serta mempergunakan kendaraan ketika melakukan 
perjalanan (khususnya masyarakat Tangtu) merupakan sebagian buyut yang berlaku pada masyarakat Baduy (Permana 2001; Garna 1988; Djoewisno 1987). Masyarakat Kampung Naga pamali memasuki leuweung larangan (hutan larangan), pamali mengangkut barang dengan menggunakan alat angkut atau dihela oleh hewan pengangkut. Mereka harus memikul (manggul) sendiri barang bawaan seberat apapun, pamali memasuki hutan larangan dan memanfaatkan kayunya walaupun hanya sebatang ranting (Suganda, 2006). Proses pembiasaan yang dilakukan melalui penjayaan pamali dilakukan sebagai bentuk pendidikan agar generasi muda dapat menjalani kehidupan secara teratur dan sesuai dengan tata nilai warisan leluhur.

Keunikan dan kekhasan serta keteguhan masyarakat Kampung Naga dalam memertahankan tradisi, menarik perhatian banyak peneliti dari berbagai latar belakang keilmuan untuk mempelajari dan mengambil manfaat dari pola kehidupan yang sederhana. Para peneliti tersebut, diantaranya Ismudiyanto (1987), Suhamihardja dan Sariyun (1991/1992), Wessing (1997), Hutagalung (2008), Suganda (2009), Bachtiar (2010), dan Hermawan (2011).

Penelitian ini lebih memfokuskan pada proses pewarisan nilai dari generasi tua kepada generasi muda sebagai bentuk komunikasi lintas generasi. Proses komunikasi tersebut dimaksudkan agar tatanan nilai masyarakat yang selama ini dianut dan berkembang di tengah masyarakat Kampung Naga dapat tetap dipertahankan serta menjadi bagian dalam kehidupan seharihari.

Tata kehidupan masyarakat Kampung Naga tidak jauh berbeda dengan tata kehidupan masyarakat Sunda lainnya. Kepatuhan mereka pada tata nilai yang diwariskan para leluhur menjadikan kehidupan mereka bersahaja jauh dari kehidupan yang penuh persaingan.

Permasalahan yang diangkat pada penelitian ini difokuskan pada bentuk komunikasi lintas generasi yang terjadi pada masyarakat tradisional Sunda, yaitu bagaimana proses komunikasi lintas generasi yang berlangsung pada masyarakat Kampung Naga berkaitan dengan pewarisan nilai dan adat istiadat?

Melalui permasalahan tersebut, tujuan yang ingin dicapai adalah diperolehnya gambaran lengkap tentang bentuk-bentuk komunikasi lintas generasi dan proses komunikasi yang berlangsung pada masyarakat tradisional Sunda.

\section{LANDASAN KONSEPTUAL}

Kebudayaan menurut pengertian antropologi, merupakan "keseluruhan sistem gagasan, tindakan, dan hasil karya manusia dalam rangka kehidupan masyarakat yang dijadikan milik diri manusia dengan belajar" (Koentjaraningrat, 1990). Menurut LeviStrauss (2007), budaya pada hakikatnya adalah sistem simbolik atau konfigurasi sistem perlambangan. Untuk memahami perangkat lambang budaya tertentu, orang harus lebih dahulu melihatnya dalam kaitan dengan keseluruhan sistem tempat di mana sistem perlambangan tersebut menjadi bagian.

Identitas masyarakat tercermin pada orientasi yang menunjukkan pandangan hidup dan sistem nilai masyarakat; persepsi yang menggambarkan tanggapan masyarakat terhadap dunia luar; pola dan sikap hidup yang mewujudkan tingkah laku masyarakat sehari-hari; dan gaya hidup yang mewarisi perikehidupan masyarakat. Sebagai ekspresi diri serta perwujudan kepribadian masyarakat, maka masing-masing menunjukkan kearifan lokal yang menjadi ciri dan inti kehidupan budaya masyarakat. Kedudukan kearifan lokal penting dalam kehidupan berbangsa dan bermasyarakat, karena merupakan kekuatan yang mampu bertahan terhadap unsur-unsur yang datang dari luar dan mampu berkembang pada masa-masa mendatang. (Poespowardojo, 1986).

Konsep tata ruang suatu masyarakat akan berkaitan dengan sistem religi mereka, terutama yang berkaitan dengan pandangan dunianya. Secara khusus, pandangan dunia suatu masyarakat dapat terlihat dari kosmologi mereka. Keyakinan tentang kosmos pada umumnya berkaitan erat dengan 
kepercayaan terhadap kekuatan adi-kodrati yang menguasai, mengendalikan, atau melandasinya. Oleh karena itu, dapat dipahami betapa pentingnya pemahaman dan penghayatan kosmos sebagai prasyarat untuk mencapai kebahagiaan hidup batiniah manusia (Sedyawati 1995 dalam Permana 2006). Pada masyarakat Kampung Naga, aturan-aturan kehidupan masyarakatnya memiliki hubungan antara agama, kepercayaan, dan kosmologi. Dengan kekuatan tersebut, sanksi-sanksi aturan agama dan adat yang berhubungan dengan permasalahan tata ruang lingkungan dan aturan bangunan sangat ditaati oleh masyarakat Kampung Naga. Menurut Gudykunst dan Kim (1992) dalam Mulyana (2000), penyandian pesan dan penyandianbalik pesan merupakan proses interaktif yang dipengaruhi oleh filter-filter konseptual yang dikategorikan menjadi faktor-faktor budaya, sosiobudaya, psikobudaya dan faktor lingkungan.

Untuk menjaga tatanan nilai kehidupan yang berlaku tetap terjaga, masyarakat melakukan pewarisan nilai kepada generasi berikut melalui proses komunikasi berkelanjutan antara generasi tua dengan generasi muda. Selain itu, simbolsimbol di masyarakat merupakan bagian penting sistem komunikasi di tengah masyarakat, termasuk masyarakat tradisional. Ritzer dan Goodman (2007) mengutip tokoh interaksionisme simbolik (Blumer,1969; Manis dan Meltzer, 1978; Rose, 1962; Snow, 2001) yang mengemukakan bahwa prinsipprinsip teori simbolik adalah : (1) Tidak seperti binatang Manusia dibekali kemampuan berpikir; (2) Kemampuan berpikir dibentuk oleh interaksi sosial; (3) Dalam interaksi sosial orang belajar makna dan simbol yang memungkinkan mereka menerapkan kemampuan khas mereka sebagai manusia, yakni berpikir; (4) Makna dan simbol memungkinkan orang melanjutkan tindakan dan interaksi yang khas manusia; (5) Orang mampu memodifikasi atau mengubah makna dan simbol yang mereka gunakan dalam tindakan dan interaksi berdasarkan interpretasi mereka atas situasi; (6) Orang mampu melakukan modifikasi dan perubahan ini karena antara lain kemampuan mereka berinteraksi dengan diri sendiri yang memungkinkan mereka memeriksa tahapantahapan tindakan, menilai keuntungan dan kerugian relatif, dan kemudian memilih salah satunya; (7) Pola-pola tindakan dan interaksi yang jalin-menjalin ini membentuk kelompok dan masyarakat.

Agar keseimbangan lingkungan tetap terjaga, pewarisan nilai perlu dilakukan kepada generasi muda melalui proses pembiasaan dalam kehidupan sehari-hari dan bahasa merupakan sarana utama dalam proses pewarisan nilai. Menurut Levi-Strauss (2007), kita dapat memperlakukan bahasa sebagai kondisi kebudayaan, karena dengan cara berbahasalah individu memperoleh kebudayaan dari kelompoknya. Orang mengajar dan mendidik anak dengan berbicara. Orang mengomeli dan menyanjung dengan kata-kata. Dengan menempatkan diri pada sudut pandang yang lebih teoretis, bahasa juga tampak sebagai kondisi kebudayaan dalam pengertian bahwa kebudayaan memiliki arsitektur yang sama dengan arsitektur bahasa. Satu sama lain dibangun dengan cara oposisi dan korelasi, dengan kata lain melalui hubungan yang logis. Dengan demikian kita bisa mempertimbangkan bahasa sebagai pondasi yang ditujukan untuk menerima struktur yang lebih kompleks namun kadang-kadang dengan tipe yang sama seperti struktur yang kita miliki, serta berhubungan dengan kebudayaan yang dipertimbangkan dengan berbagai aspeknya.

Sebagian besar individu akan menyesuaikan dirinya atau tunduk kepada aturan yang ditetapkan oleh kelompoknya, betapa pun aturan tersebut tidak masuk akal atau aneh. Kondisi demikian merupakan bukti bahwa lembaga adat menentukan aturan mutlak bagi anggota kelompoknya. Kebanyakan orang tunduk kepada bentukbentuk khusus kebudayaannya karena mereka pada kodratnya mudah dipengaruhi dan mudah berubah. Mereka membiarkan dirinya berkelakuan seperti yang dikehendaki oleh kekuatan masyarakat di mana mereka dilahirkan (Bennedict, 1962).

Kondisi ini disebabkan karena 
keketatan struktural merupakan dimensi yang berfokus pada norma, aturan, dan batasan yang berlaku pada anggota suatu komunitas. Budaya yang longgar hanya menerapkan sedikit peraturan dan batasan atas perilaku, sementara di dalam budaya yang ketat aturan dan batasan perilaku, norma dan aturan budaya cenderung jelas dan harus ditaati. Dalam budaya ketat, jika ada anggota komunitas yang melanggar norma dan aturan budaya dikenakan sanksi. Sebaliknya dalam komunitas budaya longgar, para anggota yang melanggarnya tidak akan dikenai sanksi sekeras pada budaya ketat (Gudykunst dan Kim, 1997).

Agar budaya benar-benar menjadi dirinya sendiri dan menghasilkan sesuatu maka kebudayaan tersebut dan para anggotanya harus yakin akan orisinalitasnya, bahkan sampai taraf tertentu mereka juga harus yakin akan superioritas di atas kebudayaan lain (Levi-Strauss, 2005). Untuk mencapainya diperlukan komunikasi intensif diantara anggota masyarakat pendukung kebudayaan tersebut, karena menurut Watson dan Pavlov dalam Aripudin (2011), bahwa segala tingkah laku manusia adalah hasil dari conditioning, yaitu hasil latihan atau kebiasaan-kebiasaan mereaksi terhadap syarat-syarat atau rangsangan tertentu yang dialaminya dalam kehidupan. Selain itu, komunikasi merupakan suatu proses yang berlangsung secara terus menerus dan berkelanjutan serta tidak memiliki titik awal dan tidak memiliki titik akhir (Wiryanto, 2002). Kenyataan ini menunjukkan bahwa komunikasi bersifat dinamis dan transaksional, dimana kemudian akan terjadi perubahan dalam setiap diri peserta komunikasi tersebut. Dalam proses komunikasi, para peserta komunikasi saling memengaruhi, seberapa kecil pun sangat berpengaruh, baik lewat komunikasi verbal maupun komunikasi non verbal. Pengaruhpengaruh tersebut akan menimbulkan pengetahuan dan perilaku yang baru.

$$
\text { Menurut Model Komunikasi }
$$

Gudykunst dan Kim, mengasumsikan dua orang yang setara dalam berkomunikasi, masing-masing sebagai pengirim dan sekaligus sebagai penerima, atau keduanya sekaligus melakukan penyandian (encoding) dan penyandian-balik (decoding). Karena itu, tampak pula bahwa pesan suatu pihak sekaligus juga adalah umpan balik bagi pihak lainnya. Dan hal itu menunjukkan bahwa setiap kita berkomunikasi, secara serentak kita menyandi dan menyandi balik pesan. Dengan kata lain, komunikasi tidak statis, kita tidak menyandi suatu pesan dan tidak melakukan apa-apa hingga kita menerima umpan balik (Mulyana, 2000).

Menurut Wilbur Schramm, bidang pengalaman merupakan faktor penting terjadinya komunikasi. Apabila bidang pengalaman komunikator sama dengan bidang pengalaman komunikan, komunikasi akan berlangsung lancar. Sebaliknya kalau pengalaman komunikan tidak sama dengan pengalaman komunikator, akan timbul kesukaran untuk mengerti satu sama lain, atau dengan kata lain tidak komunikatif (Nasution, 2012).

Berdasarkan uraian tersebut, pewarisan nilai melalui pembiasaan dalam kehidupan sehari-hari perlu dilakukan di tengah masyarakat agar terjadi kesamaan pengalaman antara komunikator dengan komunikan. Proses tersebut dilakukan melalui pewarisan nilai dari orang tua kepada generasi muda yang dilakukan melalui proses bertanya, mengamati, meniru, mendengarkan, dan membaca. Pedoman untuk bertanya adalah jika akan bertanya sesuatu harus bertanya kepada ahlinya (Danasasmita, 1987). Pedoman untuk mengamati dan meniru adalah mengamati perbuatan baik dan perbuatan buruk orang lain, yang baik hendaknya ditiru, sedangkan yang buruk harus dihindari. Metode mendengarkan yaitu mendengarkan/menyimak petuah atau pelajaran yang disampaikan oleh guru. Petuah atau pelajaran tersebut diresapi yang kemudian diamalkan dalam kehidupan seharihari (Ekadjati, 2004). Berkenaan dengan metode mendengarkan, Naskah Sewaka Darma mengajarkan "Anakku harus waspada, dengarkan sabda sang pandita, ingatlah jangan sampai lupa, lalu nikmatilah dalam hati" (Danasasmita, 1987). 


\section{Kampung Naga}

Sejarah Kampung Naga

Menurut kepercayaan masyarakat Kampung Naga, leluhur mereka adalah Eyang Dalem Singaparana atau Eyang Galunggung yang makamnya terdapat di leuweung karamat (hutan keramat), sebelah barat Kampung Naga. Saat ini makam tersebut dikeramatkan dan selalu diziarahi oleh warga Kampung Naga. Siapa Eyang Dalem Singaparana sampai sekarang belum diketahui secara pasti, karena warga Kampung Naga yang ditanya soal tersebut selalu menjawab bahwa leluhur kami adalah Eyang Dalem Singaparana tanpa mau menjelaskan asal usulnya. Pertanyaan berkenaan dengan asal usul Eyang Dalem Singaparana, selalu dijawab warga dengan jawaban tidak tahu.

Berkenaan dengan asal usul leluhur Kampung Naga, yaitu Eyang Dalem Singaparana, banyak versi yang berkembang di kalangan peneliti Kampung Naga, diantaranya pendapat yang mengatakan bahwa Eyang Singaparana adalah salah seorang pimpinan tentara Mataram yang tidak pulang kembali ke Mataram setelah gagalnya penyerbuan pasukan Mataram ke Batavia. Pada perjalanan pulang itulah ia memutuskan untuk menetap di daerah yang kelak kemudian menjadi Kampung Naga dan mengembangkan ajaran Islam beserta pengikutnya setelah mendapat petunjuk dari Yang Maha Kuasa.

\section{Perekonomian}

Pengamatan di lapangan menunjukkan, masyarakat Kampung Naga merupakan masyarakat agraris bermata pencaharian utama sebagai petani dengan hasil utamanya adalah padi. Sebagai seorang petani mereka mengolah sawah dengan mengikuti petunjuk leluhur yang dilakukan secara turun temurun, yaitu dengan hanya menggunakan tenaga manusia dalam mengolah lahan sampai memetik hasilnya. Untuk memenuhi kebutuhan asupan makanan keluarga dan untuk kepentingan upacara adat, mereka juga memelihara hewan ternak serta membudidayakan ikan. Selain itu, mereka juga membuat berbagai kerajinan tangan berbahan baku bambu dan kayu yang hasilnya dipergunakan untuk kepentingan sendiri dan kegiatan adat, serta dijajakan sebagai souvenir kepada pendatang/wisatawan yang berkunjung ke Kampung Naga.

\section{METODE PENELITIAN}

Untuk menjawab permasalahan yang diajukan dalam penelitian ini, metode penelitian yang dipergunakan adalah metode penelitian deskriptif dengan pendekatan kualitatif. Pengumpulan data dilakukan dengan cara observasi, dokumentasi, dan wawancara. Melalui penerapan metode penelitian tersebut diharapkan dapat terjaring data dan informasi berkenaan dengan bentukbentuk komunikasi lintas generasi yang terjadi pada proses pewarisan nilai di masyarakat. Pengumpulan data dilakukan pada bulan Mei 2011.

\section{HASIL DAN PEMBAHASAN}

Masyarakat Kampung Naga dalam kehidupan sehari-hari berupaya untuk tetap mempertahankan kesederhanaan dalam menjalani kehidupan. Hal ini tercermin pada pandangan hidup mereka "hirup mah kudu tungkul ka jukut, tanggah $k a$ sadapan" (menunduk harus ke rumput, menengadah harus ke tempat menyadap) yang artinya dalam hidup kita harus melihat kenyataan, tidak iri dengki terhadap kemajuan atau keberhasilan yang dicapai orang lain. Melalui ajaran ini diharapkan setiap individu dapat menerima apa yang menjadi rezekinya, dan tidak bernafsu untuk memiliki sesuatu yang bukan menjadi miliknya. Selain itu, masyarakat Kampung Naga dalam menjalani kehidupan memiliki prinsip "teu saba teu soba, teu banda teu boga, teu weduk teu bedas, teu gagah teu pinter" (tidak bepergian tidak berhasil, tidak berharta tidak memiliki apa-apa, tidak kebal tidak kuat, tidak gagah tidak pandai). Maksudnya adalah manusia pada dasarnya tidak mempunyai kelebihan apapun sehingga tidak perlu sombong. 
Kesederhanaan dalam menjalani kehidupan menjadi penting yang dicerminkan dengan menerima rezeki apa adanya. Pandangan hidup tersebut diwariskan secara turun temurun dari generasi tua kepada generasi berikut. Tujuannya agar generasi muda dapat mewarisi nilai-nilai positif generasi sebelumnya.

Proses komunikasi pada masyarakat Kampung Naga dapat dikelompokkan menjadi dua: (1) komunikasi langsung atau komunikasi verbal dan (2) komunikasi tidak langsung atau komunikasi non verbal. Komunikasi langsung merupakan komunikasi yang dilakukan melalui komunikasi lisan antara orang tua dengan anak-anaknya, antara pemimpin kampung (adat) dengan anggota masyarakatnya, dan komunikasi yang terjalin antara anggota masyarakat. Komunikasi tidak langsung merupakan komunikasi yang berlangsung melalui simbol-simbol atau proses pembiasaan yang berlangsung di tengah masyarakat.

Berkaitan dengan proses komunikasi lintas generasi, Munir (39 tahun), warga Kampung Naga, menjelaskan bahwa "kami dalam berbagai kesempatan selalu berupaya untuk memperkenalkan tata nilai dan segala sesuatu yang berkaitan dengan adat istiadat kepada anak-anak kami". Selain orang tua, para sesepuh kampung (pimpinan adat) juga dalam berbagai kesempatan selalu mengingatkan warganya agar tidak meninggalkan ketentuan-ketentuan yang telah digariskan leluhur. Tujuannya agar mereka dapat mengenal, dan mematuhi berbagai ketentuan adat yang berlaku.

\section{Komunikasi Lintas Generasi}

Berkaitan dengan bentuk komunikasi lintas generasi pada masyarakat Kampung Naga, penulis mengelompokkan bentuk komunikasi tersebut menjadi tiga, yaitu pamali, pembiasaan, dan pengondisian dengan lingkungan alam.

\section{Pamali Sebagai Bentuk Komunikasi}

Bentuk komunikasi lisan lainnya yang dilakukan dalam proses pewarisan nilai adalah pamali. Menurut kamus Basa Sunda
(Satjadibrata, 2005), pamali mempunyai pengertian larangan karuhun (merupakan sesuatu yang dilarang oleh leluhur); menurut kamus Basa Sunda (LBSS, 1995), pamali mempunyai pengertian sok aya matakna nurutkeun kapercayaan karuhun (suka ada akibatnya berdasarkan kepercayaan leluhur). Berdasarkan kedua pengertian tersebut, maka pamali merupakan bentuk larangan untuk melakukan sesuatu, karena jika perbuatan tersebut dilakukan akan menimbulkan dampak bagi si pelaku. Penjayaan pamali dalam kehidupan sehari-hari dilakukan agar individu menjalani kehidupan secara teratur sesuai dengan tata warisan leluhur.

Bagi masyarakat Kampung Naga, pamali merupakan salah satu bagian dari tata aturan yang harus dipatuhi dalam menjalani kehidupan sehari-hari. Menurut keterangan Ateng Jaelani (56 tahun), lebe Kampung Naga, "dalam menjalani kehidupan di Kampung Naga, masyarakat harus mematuhi aturan yang berlaku di Kampung Naga secara turun temurun. Salah satunya berbentuk pamali". Hal senada juga disampaikan oleh Munir (39 tahun), warga Kampung Naga, yang baginya sangat takut untuk melanggar pamali. Jika terlanjur melanggar pamali, dia akan berusaha untuk meminta maaf kepada kepala adat (kuncen) dan kepada leluhur. Ketika disinggung adakah balasan/sanksi yang diterima ketika melanggar pamali, Munir menjelaskan, "sampai saat ini belum ada yang mendapat sanksi karena mereka tidak berani melanggar pamali sebab takut untuk melakukan perbuatan yang dianggap pamali”. Selanjutnya Munir menjelaskan, "ketakutan masyarakat Kampung Naga untuk melanggar pamali, karena sanksinya jika tidak kita rasakan secara langsung, maka sanksi itu mungkin akan menimpa anak-anak dan keturunan kita".

Masyarakat Kampung Naga dalam menjalani kehidupan sehari-hari diatur oleh berbagai aturan adat atau pantang larang yang berupa pamali. Menurut Munir (39 tahun) warga Kampung Naga, pamali yang berlaku pada masyarakat Kampung Naga, diantaranya: pamali memasuki leuweung larangan (hutan larangan), pamali mengangkut barang dengan menggunakan 
alat angkut atau dihela oleh hewan pengangkut. Mereka harus memikul (manggul) sendiri barang bawaan seberat apa pun, pamali memanfaatkan kayu dari leuweung larangan walaupun hanya sebatang ranting.

Keberadaan pamali dikomunikasikan kepada masyarakat sejak mereka kecil dalam berbagai kesempatan. Sejak dini mereka ditanamkan untuk selalu merasa bersalah jika melanggarnya. Semua itu dilakukan karena mereka percaya keberadaan pamali sebagai bentuk aturan adat positif warisan leluhur guna mengatur agar mereka tidak salah dalam menjalani kehidupan di dunia.

\section{Pembiasaan}

Agar nilai-nilai masyarakat dapat berhasil diwariskan, maka di tengah masyarakat perlu dilakukan proses pembiasaan berkenaan dengan tata nilai yang berlaku turun temurun pada realita kehidupan sehari-hari. Tujuannya agar warga tergerak hati nuraninya untuk mengikuti aturan-aturan yang berlaku sehingga dapat meningkatkan rasa percaya diri mereka dalam menjalani kehidupan yang sesuai dengan tuntunan adat.

Pengamatan penulis menunjukkan, proses pembiasaan dilakukan oleh orang tua dan masyarakat kepada anak-anak mereka. Anak-anak sejak kecil dibiasakan untuk selalu mematuhi aturan dan nilai-nilai yang berlaku, dan dilakukan tidak sekedar melalui kata-kata namun melalui perbuatan yang dilakukan oleh orang tua. Menurut keterangan Munir (39 tahun), warga Kampung Naga, kuncen Kampung Naga beserta pimpinan adat lainnya selalu memberikan contoh yang baik kepada masyarakat dalam menjalani kehidupan sehari-hari. Perilaku itu jelas dilakukan juga oleh orang tua dan masyarakat lainnya. Tujuannya agar anak-anak dapat menirunya dan tetap mempertahankannya di kemudian hari.

Proses pembiasaan juga tampak pada keadaan lingkungan permukiman yang sederhana dan seragam, seolah tidak ada perbedaan di antara mereka. Kondisi lingkungan tersebut akan menumbuhkan kesan mendalam pada diri mereka dalam menjalani kehidupannya kelak dikemudian hari.

\section{Pengondisian dengan Lingkungan Alam}

Pengondisian dengan alam merupakan bentuk penyesuaian masyarakat Kampung Naga dengan lingkungan alam di mana mereka menetap. Aturan adat yang melarang perubahan terhadap tatanan lingkungan yang selama ini mereka anut, pelanggaran yang dilakukan akan melahirkan sanksi adat. Penyesuaian dengan kondisi alam sekitar tampak pada bentuk bangunan dan bahan bangunan yang dipergunakan, serta penataan ruang.

\section{Bangunan Sebagai Bentuk Komunikasi}

Masyarakat adat di tatar Sunda memandang rumah atau bangunan tidak hanya sebagai tempat berteduh dari teriknya matahari atau derasnya hujan. Bagi mereka, rumah mempunyai makna yang lebih luas dari sekedar makna sebagai tempat tinggal, namun lebih mendalam berkenaan dengan konsep kosmologinya yang tercermin dalam pola penataan kampung, bentuk rumah dan pembagian ruangnya. Pada kosmologi masyarakat Sunda, alam dibagi menjadi tiga, yaitu: dunia bawah, dunia atas, dan dunia di antara keduanya atau dunia panca tengah. Dunia bawah merupakan tempat bagi mereka yang sudah meninggal, sedang dunia atas merupakan tempat Sang Pencipta, dan manusia hidup dan beraktivitas di dunia panca tengah atau diantara dunia bawah dengan dunia atas. Sehingga bangunan rumah pada masyarakat tradisional Sunda dibangun dengan menggunakan kaki atau tatapakan, merupakan bangunan panggung.

Pengamatan di lapangan menunjukkan, bangunan rumah di Kampung Naga bentuk, ukuran, dan bahannya seragam. Rumah berbentuk rumah panggung berdenah empat persegi panjang, dinding bilik bambu bercat putih dan lantai kayu atau bambu. Atap bangunan (suhunan) merupakan atap panjang atau suhunan julang ngapak yang ditutup oleh ijuk. Setiap atap rumah tidak boleh menutupi atap bangunan di sebelahnya. Ujung atap bagian atas dipasang gelang- 
gelang yang tiangnya terbuat dari bambu sepasang dengan tinggi sekitar setengah meter dari puncak atap sehingga menyerupai huruf "V" yang juga disebut capit gunting atau cagak gunting atau capit hurang. Bambu gelang-gelang tersebut dililit tambang ijuk yang bagian atasnya ditutup batok kelapa, sehingga terlindung dari terik matahari dan guyuran hujan.

Berkenaan dengan penggunaan bahan bangunan dalam membangun rumah, Munir (39 tahun), warga kampung Naga, menjelaskan, "bahan bangunan untuk membangun rumah berasal dari lingkungan setempat, kecuali bagian tertentu yang tidak bisa disediakan secara mandiri seperti paku dan kaca. Semua proses pembangunan rumah dilakukan sesuai dengan pikukuh (petunjuk/ajaran) leluhur, mereka pamali (tabu/pantang) untuk membangun rumah tembok dengan atap genting, walau secara ekonomi memungkinkan. Selain itu, rumah di Kampung Naga tidak boleh menghadap ke arah timur karena dianggap melanggar kodrat alam, sehingga setiap rumah akan selalu menghadap ke utara atau ke selatan dan saling membelakangi atau saling berhadapan, tidak ada satu rumah pun yang menghadap belakang rumah yang lainnya".

Bangunan-bangunan rumah di

Kampung Naga saat ini sudah mengalami perubahan, yaitu penambahan jendela dan kaca sehingga cahaya matahari lebih banyak masuk ke dalam rumah. Sebelum terjadi peristiwa bumi hangus yang dilakukan oleh Gerombolan DI/TII pimpinan Kartosuwiryo pada tahun 1956, rumah-rumah di Kampung Naga belum dilengkapi jendela atau kaca. Pada saat pembangunan kembali bangunan rumah yang sebelumnya dibumihanguskan, masyarakat Kampung Naga menambahkan kaca dan jendela di dinding dan kaca di atap (Suganda, 2006).

Bangunan lainnya yang berdiri di Kampung Naga, adalah masjid, bale patemon (balai pertemuan), leuit lembur (lumbung kampung), dan bumi ageung (rumah besar). Pengamatan di lapangan menunjukkan, tidak berbeda dengan bangunan rumah tinggal, bangunan-bangunan tersebut merupakan bangunan panggung dengan orientasi timur- barat dan bahan bangunannya berasal dari alam setempat.

Masjid Kampung Naga merupakan tempat kegiatan keagamaan dan adat warga Kampung Naga. Tidak berbeda dengan bangunan rumah tinggal, bangunan masjid merupkan bangunan panggung yang berdenah empat persegi panjang, atapnya berbentuk atap panjang (julang ngapak) yang ditutup oleh ijuk. Dindingnya ditutup oleh bilik (anyaman bambu) yang dicat dengan menggunakan kapur cat. Bangunan ini dilengkapi dengan dua tempat wudu, yaitu di bagian utara dan di bagian selatan dekat pintu masuk masjid. Selain itu, masjid ini dilengkapi dengan satu kentongan dan beduk ukuran besar sebagai sarana untuk memberitahu datangnya waktu Shalat. Bale patemon merupakan bangunan tempat berkumpul warga untuk melakukan musyawarah kampung serta kegiatan lainnya termasuk difungsikan sebagai tempat menerima tamu, terutama rombongan. Tidak berbeda dengan bangunan rumah dan bangunan lainnya, merupakan bangunan panggung dengan denah persegi empat, dinding ditutup oleh bilik dan beratap panjang (julang ngapak) yang ditutup oleh ijuk. Bangunan lainnya, adalah leuit lembur (lumbung kampung) merupakan tempat menyimpan padi hasil pertanian (panen) yang menjadi kas kampung.

Bumi ageung (rumah besar), yaitu bangunan rumah tinggal yang bentuk, ukuran, dan denahnya sama dengan bangunan rumah tinggal lainnya namun dikeramatkan dan tidak sembarang orang diperkenankan memasuki rumah tersebut, hanya mereka yang diizinkan oleh kuncen yang dapat masuk ke dalamnya. Perbedaan bangunan ini dengan rumah tinggal lainnya di Kampung Naga, adalah bangunannya tidak dilengkapi dengan jendela dan dindingnya berbahan anyaman bambu (bilik) yang disebut bilik sisig, serta dibatasi oleh dua lapis pagar bambu yang disebut pager jago. Fungsi bangungan adalah sebagai tempat penyimpanan benda pusaka masyarakat Kampung Naga. Bangunan rumah ini dijaga dan dipelihara kebersihannya oleh dua orang wanita yang sudah tidak haid lagi atau sudah 
memasuki masa menopause. Hal ini menunjukkan posisi rumah tinggi nilai kesakralannya di tengah masyarakat Kampung Naga.

\section{Ruang Sebagai Bentuk Komunikasi}

Kawasan permukiman masyarakat Kampung Naga merupakan tempat warga masyarakat setempat hidup dan beraktivitas. Aturan adat telah membagi zonasi ruang agar keseimbangan ekosistem lingkungan tidak rusak. Hal ini tampak pada pembagian zonasi lingkungan Kampung Naga, yaitu kawasan hutan lindung dan hutan karamat (keramat), kawasan permukiman, serta kawasan luar. Berdasarkan pembagian tersebut, tampak keteraturan dalam peruntukkan ruang di lingkungan masyarakat. Keteraturan tersebut terus dipertahankan hingga saat ini dan diharapkan tetap dipertahankan pada waktu mendatang.

Kawasan hutan lindung (leuweung biuk) dan hutan keramat (leuweung karamat). Hutan keramat merupakan kawasan yang dikeramatkan dan selalu dijaga kesuciannya karena di hutan keramat terdapat makam Eyang Mbah Dalem Singaparana, leluhur masyarakat Kampung Naga. Menurut keterangan Ateng Jaelani (56 tahun), lebe Kampung Naga, untuk masuk ke hutan keramat tidak bisa sembarangan, hanya mereka yang mempunyai niat suci untuk berziarah ke makam leluhur yang dapat memasuki kawasan hutan, dan ziarah tidak boleh dilakukan pada hari-hari pantangan, yaitu Selasa, Rabu, dan Sabtu. Pada hari-hari tersebut juga warga Kampung Naga dilarang untuk membicarakan leluhurnya. Hutan lainnya yang dijaga kelestariannya adalah leuweung biuk atau hutan tutupan.

Kawasan berikutnya adalah permukiman/kampung yang merupakan tempat masyarakat mendirikan berbagai bangunan: masjid, leuit, dan rumah. Kawasan ini dibatasi oleh pagar bambu yang disebut pager jaga. Di kawasan ini berdiri rumah seluruh warga Kampung Naga, masjid, balai pertemuan (bale patemon), lumbung kampung (leuit lembur) dan bumi ageung (rumah besar). Pada kawasan ini tidak diperkenankan membangun jamban atau MCK. Tempat wudu yang berada di samping masjid pun tidak dilengkapi oleh jamban, hanya difungsikan sebagai tempat bersuci. Semua kegiatan mandi, cuci, dan kakus dilakukan di jamban yang dibangun di luar kawasan permukiman.

Kawasan yang berikutnya adalah kawasan luar, merupakan kawasan di luar kawasan permukiman Kampung Naga (di luar pagar) yang merupakan tempat masyarakat Kampung Naga beraktivitas kebersihan. Di kawasan ini terdapat kolam ikan yang di atasnya dibangun jamban atau MCK, kandang kambing, dan saung lisung (bangunan tempat menumbuk padi, di tempat ini disimpan lesung panjang terbuat dari kayu). Kawasan ini berbatasan langsung dengan sungai Ciwulan yang merupakan batas Kampung Naga di bagian timur.

Berdasarkan hasil pengamatan lapangan yang diuraikan di atas, pola permukiman masyarakat Kampung Naga merupakan pola permukiman yang terkonsentrasi (berkelompok), bangunan rumah terkumpul di satu tempat. Tata letak dan susunan bangunannya berbentuk linear mengikuti topografi lahan yang miring. Rumah-rumah dan bangunan sakral dibangun tersebar mengikuti bentuk lembah pegunungan dengan pusatnya adalah lahan terbuka di depan masjid yang menjadi tempat berbagai kegiatan masyarakat Kampung Naga. Masyarakat Kampung Naga juga peduli akan kebersihan diri dan lingkungan.

Pengamatan di lapangan menunjukkan, pemanfaatan air dilakukan dengan cara mengalirkan air menggunakan pipa dari mata air ke kampung. Air tersebut kemudian dialirkan ke masjid untuk kepentingan ibadah, serta ke pancuran atau jamban yang dibangun di atas kolam di luar pager jaga untuk memenuhi hajat hidup sehari-hari. Menurut keterangan Munir (39 tahun), "setiap rumah yang ada di Kampung Naga tidak boleh memiliki jamban di rumah. Jamban-jamban mereka berada di atas kolam yang berada di luar pagar (pager jaga)". Setelah ditampung di kolam, limpasan air kembali ke sungai. Hal ini menunjukkan pemanfaatan air dilakukan dengan tidak merusak ekosistem. 
Air bersih yang dimanfaatkan, limbahnya tidak langsung masuk ke sungai karena dinetralisir terlebih dahulu di kolam, sehingga air yang kembali ke sungai relatif tetap bersih.

\section{Pembahasan}

Komunikasi lintas generasi dalam bentuk pewarisan nilai merupakan hal yang penting di tengah masyarakat dengan tujuan agar generasi berikut mewarisi nilai-nilai positif dan dapat mempertahankannya dalam kehidupan dan tidak terpengaruh oleh masuknya nilai-nilai negatif dari luar, karena agar budaya benar-benar menjadi dirinya sendiri dan menghasilkan sesuatu, maka kebudayaan tersebut dan para anggotanya harus yakin akan orisinalitasnya, bahkan sampai taraf tertentu mereka juga harus yakin akan superioritas di atas kebudayaan lain (Levi-Strauss, 2005). Selain itu, perilaku individu dalam menjalani kehidupan seharihari merupakan hasil dari proses pembiasaan yang berlangsung secara berkelanjutan di tengah masyarakat. Penjayaan pamali dan proses pembiasaan lainnya dalam kehidupan sehari-hari merupakan bentuk pewarisan nilai yang dilakukan masyarakat tradisional di tatar Sunda, termasuk masyarakat Kampung Naga.

Penjayaan pamali di lingkungan masyarakat Kampung Naga dilakukan sebagai bentuk penanaman nilai kehidupan, yaitu "hirup mah kudu tungkul ka jukut, tanggah ka sadapan" (menunduk harus ke rumput, menengadah harus ke tempat menyadap) yang artinya dalam hidup kita harus melihat kenyataan, tidak iri dengki terhadap kemajuan atau keberhasilan yang dicapai orang lain. Selain itu, pada masyarakat Kampung Naga juga ditanamkan prinsip hidup "teu saba teu soba, teu banda teu boga, teu weduk teu bedas, teu gagah teu pinter" (tidak bepergian tidak berhasil, tidak berharta tidak memiliki apa-apa, tidak kebal tidak kuat, tidak gagah tidak pandai). Maksudnya adalah manusia pada dasarnya tidak mempunyai kelebihan apapun sehingga tidak perlu sombong. Kesederhanaan dalam menjalani kehidupan menjadi penting yang dicerminkan dengan menerima rezeki apa adanya.

Berdasarkan uraian tersebut, pamali bagi masyarakat Kampung Naga merupakan bentuk peraturan yang tidak tertulis, namun keberadaannya mampu menjadi pengendali mereka dalam bertindak dan berperilaku di tengah masyarakat. Dalam menjalani kehidupan, mereka berusaha semaksimal mungkin untuk tidak melanggar apa yang dilarang leluhur melalui pamali. Hal ini tampak pada tidak pernah ditanyakannya alasan mengapa suatu pekerjaan itu pamali dilakukan. Kepatuhan pada orang tua dan pemimpin adat yang dilakukan masyarakat Kampung Naga tampak dari tetap bertahannya nilai tradisi warisan leluhur di tengah masyarakat. Hal ini tampak pada kegiatan pertanian, mereka tidak boleh menggarap sawah dengan menggunakan bajak dan traktor. Pengolahan tanah untuk kegiatan pertanian cukup mempergunakan tenaga manusia semata. Selain itu, mengangkut barang dan hasil pertanian tidak boleh menggunakan hewan penghela atau kendaraan pengangkut. Semua barang yang diangkut ke luar atau ke dalam Kampung Naga cukup dipanggul (diangkat dengan tumpuan bahu) atau ditanggung (dipikul). Menurut keterangan Munir (39 tahun), "hingga saat ini belum ada warga Kampung Naga dan mereka yang Sanaga berani melanggar pantangan yang digariskan oleh adat karena takut akan turunnya kutuk leluhur yang bisa datang kapan saja".

Bentuk komunikasi lainnya yang berlangsung di tengah masyarakat Kampung Naga, adalah dalam bentuk simbol, yaitu dalam bentuk pembagian lingkungan kampung menjadi tiga bagian, yaitu: kawasan yang dianggap keramat atau sakral, kawasan permukiman, dan kawasan terluar yang berbatasan langsung dengan sungai Ciwulan. Penetapan kawasan tersebut didasarkan perintah adat dan berlangsung secara turun temurun. Pelanggaran yang terjadi atasnya akan dikenakan sanksi dari mulai sanksi ringan berupa peringatan untuk tidak melakukan kembali sampai pengusiran ke luar kampung dan tidak boleh terlibat dalam semua kegiatan adat di Kampung Naga.

Berkenaan dengan bangunan, di 
Kampung Naga dilarang untuk mendirikan bangunan tembok. Rumah mereka adalah rumah panggung dengan bahan baku yang berasal dari lingkungan setempat. Alasan yang dikemukakan mengapa bangunan yang dibangun harus panggung adalah aturan dari leluhur. Bagi masyarakat tradisional Sunda, termasuk Kampung Naga, terdapat kepercayaan bahwa tempat tinggal manusia yang masih hidup bukan di dunia bawah (tanah) dan di dunia atas (langit), namun di dunia tengah (antara dunia bawah dan dunia atas). Hal ini disebabkan, karena manusia akan ditempatkan di dunia bawah jika ia sudah meninggal dunia, sedangkan dunia atas merupakan tempat Yang Maha Kuasa dan ruh para leluhur, akibatnya rumah tempat tinggal manusia haruslah berada diantara dua dunia tersebut atau merupakan rumah panggung (Suhamihardja, 1991/1992). Pembangunan rumah atau bangunan lain di Kampung Naga dengan menggunakan bahan sederhana dan berbentuk rumah panggung merupakan bentuk penyesuaian dengan lingkungan sekitar yang rawan akan bencana karena berada di lereng pegunungan curam serta berada di kawasan yang rawan akan bencana tektonik dan vulkanik. Kondisi ini menunjukkan bahwa pengaturan bentuk dan bahan bangunan serta penataan ruang yang dilakukan masyarakat Kampung Naga merupakan bentuk ajaran leluhur berkenaan dengan penghargaan pada alam dan lingkungan.

Berdasarkan uraian tersebut, berbagai pantang larang atau pamali berkenaan dengan pola penggunaan dan pengelolaan lahan serta kegiatan pengangkutan merupakan bentuk penyelarasan kehidupan masyarakat Kampung Naga dengan alam sekitar. Tujuannya agar alam dan lingkungan yang diamanatkan leluhur dapat dipelihara dan diwariskan kepada anak cucu di kelak kemudian hari. Demikian pula dengan bangunan rumah yang berbentuk sederhana dan bahan bangunannya berasal dari hasil alam setempat merupakan gambaran dari sikap hidup mereka yang sederhana dan apa adanya. Proses pembiasaan juga tampak dari pengelolaan sumber mata air, dimana air bersih yang bersumber dari mata air akan dibuang ke sungai setelah melalui proses netralisasi di kolam.

Uraian tersebut menunjukkan bahwa proses pembiasaan yang berlangsung di tengah masyarakat Kampung Naga secara lambat laun memengaruhi penghuninya. Pentingnya pembiasaan dalam kehidupan sehari-hari karena hanya melalui komunikasi intensif dan berkelanjutan proses pewarisan nilai kepada generasi muda dapat berlangsung dan nilai positif yang menjadi pegangan generasi tua tetap dipertahankan sebagai nilai positif di tengah masyarakat oleh generasi berikut. Hal ini sesuai dengan apa yang disampaikan oleh Watson dan Pavlov dalam Aripudin (2011), bahwa segala tingkah laku manusia merupakan hasil dari conditioning, yaitu hasil latihan atau kebiasaan-kebiasaan mereaksi terhadap syarat-syarat atau rangsangan tertentu yang dialaminya dalam kehidupan.

Pengondisian dalam menjalani kehidupan di tengah masyarakat Kampung Naga tampak pada penerapan aturan adat yang berlaku bagi semua elemen masyarakat, elemen generasi tua (komunikator) dan elemen generasi muda (komunikan) tanpa ada pengecualian. Tujuannya, agar semua elemen masyarakat memperoleh gambaran atau pengalaman yang sama berkenaan dengan tata nilai yang berlaku di tengah masyarakat. Generasi muda, sejak kecil telah dibiasakan dengan lingkungan adat dan ditekankan untuk menghormati serta melaksanakan aturan adat dalam kehidupan sehari-hari. Hal ini dikarenakan tanpa proses pembiasaan yang dilakukan sejak dini, pewarisan nilai tidak akan berlangsung sesuai dengan harapan akibat pengaruh budaya luar yang masuk melalui komunikasi yang terjalin dengan lingkungan di luar Kampung Naga.

Proses pembiasaan merupakan bentuk pengondisian yang dilakukan warga Kampung Naga kepada generasi muda. Proses ini diperlukan karena komunikasi dapat terjalin dengan baik apabila elemenelemen komunikasi tersebut mempunyai pemahaman yang sama, sebaliknya komunikasi tidak akan terjalin dengan baik jika elemen-elemen komunikasi tidak mempunyai pemahaman yang sama sebagai 
akibat dari perbedaan pengertian dan persepsi, sehingga misi dari komunikasi tersebut tidak dapat tercapai sesuai harapan. Kondisi tersebut disebabkan karena lembaga adat menentukan aturan mutlak bagi anggota kelompoknya. Kebanyakan orang tunduk kepada bentuk-bentuk khusus kebudayaannya karena mereka pada kodratnya mudah dipengaruhi dan mudah berubah. Mereka membiarkan dirinya berkelakuan seperti yang dikehendaki oleh kekuatan masyarakat di mana mereka dilahirkan (Bennedict, 1962 ).

Ketaatan dan kepatuhan masyarakat Kampung Naga terhadap tata aturan adat yang berlaku serta ketakutan akan mendapat sanksi adat dan sanksi dari leluhur apabila melanggar ketentuan yang telah digariskan menunjukkan ketatnya struktural pada masyarakat Kampung Naga. Menurut Gudykunst dan Kim (1997), keketatan struktural merupakan dimensi yang berfokus pada norma, aturan, dan batasan yang berlaku pada anggota suatu komunitas. Budaya yang longgar hanya menerapkan sedikit peraturan dan batasan atas perilaku, sementara di dalam budaya yang ketat aturan dan batasan perilaku, norma dan aturan budaya cenderung jelas dan harus ditaati. Dalam budaya ketat, jika ada anggota komunitas yang melanggar norma dan aturan budaya dikenakan sanksi.

\section{PENUTUP}

\section{Simpulan}

Pada masyarakat tradisional Sunda, termasuk masyarakat Kampung Naga, respon terhadap lingkungan dilakukan dalam kehidupan sehari-hari. Proses pewarisan nilai dilakukan kepada generasi berikut dengan tujuan agar nilai-nilai positif yang berkembang di masyarakat dapat terus dapat dipertahankan oleh generasi berikutnya. Proses tersebut dilakukan melalui komunikasi lintas generasi, antara generasi tua dengan generasi muda.

Komunikasi yang dilakukan dalam proses pewarisan nilai, bentuknya adalah penjayaan pamali. Penjayaan pamali pada masyarakat tradisional atau masyarakat adat cukup berhasil karena mereka masih memegang teguh adat istiadat warisan leluhur. Mereka tidak bertanya mengapa suatu pekerjaan pamali untuk dilakukan. Kondisi ini menunjukkan tingginya kepercayaan masyarakat kepada pemimpin adat mereka, kepada orang tua dan kepada para sesepuh kampung.

Bentuk komunikasi lintas generasi lainnya yang berlangsung di tengah masyarakat Kampung Naga, adalah komunikasi simbolik yang digambarkan dalam wujud bentuk bangunan rumah tinggal, zonasi pembagian ruang serta simbol-simbol lainnya. Tujuannya agar terjadi proses pembiasaan pada masyarakat karena tingkah laku manusia merupakan hasil pengondisian (conditioning) lingkungannya sehingga semua elemen masyarakat mempunyai pengalaman dan pemahaman yang sama tentang alam dan lingkungannya.

\section{Saran}

Proses komunikasi lintas generasi yang berlangsung pada masyarakat Sunda, termasuk masyarakat Kampung Naga, bertujuan agar nilai-nilai positif yang selama ini menjadi pegangan hidup masyarakat dapat diwariskan kepada generasi berikut. Keyakinan akan tingginya nilai budaya yang dimiliki suatu masyarakat akan terwujud jika kebudayaan dan masyarakat pendukungnya yakin akan orisinalitas, bahkan mempunyai kenyakinan pada taraf tertentu posisinya lebih tinggi dibanding kebudayaan yang lain.

\section{DAFTAR PUSTAKA}

Aripudin, Acep. (2011) Pengembangan Metode Dakwah. Jakarta: Rajawali Pers.

Bennedict, R. (1962) Pola-pola Kebudayaan (Penterjemah: Mertodipuro, S., dari Patterns of Culture). Jakarta: Pustaka Rakjat.

Danasasmita, Saleh., dkk. (1987) Sewaka Dharma, Sanghyang Siksakandang Karesian, Amanat Galunggung: Transkripsi dan Terjemahan. Bandung: Bagian Proyek Penelitian 
dan Pengkajiaan Kebudayaan Sunda (SUNDANOLOGI) Dirjen Kebudayaan, Departemen P dan K. Ekadjati, Edi. (2004) Pendidikan di Tatar Sunda (1). Pikiran Rakyat (20 - 11 2004).

Garna, Judistira. K. (1993) Masyarakat Baduy di Banten. In: Koentjaraningrat (ed.) Masyarakat Terasing di Indonesia. Jakarta: Gramedia.

Gudykunst, William B \& Young Yun Kim. 1997. Communication With Strangers, An Approach to Intercultural Communication (Third Edition), New York : McGraw-Hill.

Lembaga Basa Sastra Sunda. (1995) Kamus Basa Sunda. Bandung: LBSS.

Levi-Strauss, C. (2005) Mitos dan Makna: Membongkar Kode-Kode Budaya (Penterjemah: Hok, L.P. dari Myth and Meaning). Serpong: Marjin Kiri.

Levi-Strauss, C.(2007) Antropologi Struktural (Penterjemah: Sjams, N.R., dari Anthropologie Strukturale, PLON 1958) Yogyakarta: Kreasi Wacana.

Mulayana, Deddy. (2000). Ilmu Komunikasi : Suatu Pengantar. Bandung : Remaja Rosdakarya

Permana, R. Cecep. (2006) Tata Ruang Masyarakat Baduy. Jakarta: Wedatama Widya Sastra.

Poespowardojo, S. (1986) Pengertian Kearifan lokal dan Relevansinya dalam Modernisasi. In: Ayatrohaedi (ed.) (1986) Kepribadian Budaya Bangsa (Local Genius). Jakarta: Dunia Pustaka Jaya. Hal. 28-38.

Ritzer, George; Goodman, Douglas J. 2004. Teori Sosiologi Modern. (Penterjemah : Alimandan dari Modern Sociological Theory - 6th edition, McGraw Hill, 2003) Jakarta : Kencana
Satjadibrata. (2005) Kamus Basa Sunda. Bandung: Kiblat Buku Utama.

Sedyawati, E. (1986) Lokal Genius dalam Kesenian Indonesia. In: Ayatrohaedi (ed.). (1986) Kepribadian Budaya Bangsa (Local Genius). Jakarta: Dunia Pustaka Jaya. Hal. 186-192.

Suganda, Her. (2006) Kampung Naga Mempertahankan Tradisi. Bandung: Kiblat.

Suhamihardja, Suhandi A. \& Yugo Sariyun. (1991/1992) Kesenian, Arsitektur Rumah dan Upacara Adat Kampung Naga, Jawa Barat. Jakarta: Proyek Pembinaan Media Kebudayaan Ditjen Kebudayaan, Depdikbud.

\section{Jurnal :}

Ismudiyanto. (1987) Kosmologi Perilaku Meruang di Kampung Naga: Telaah Singkat Pola Ruang Konsentris Kampung Jawa Barat di Desa Neglasari Kecamatan Salawu Kabupaten Tasikmalaya. Media Tehnik, No. 2 Tahun IX April - Juli 1987.

\section{Internet:}

Nasution, Arif Z. (2012) Model Komunikasi Lingkungan Masyarakat Tradisional Papua...(4). Dr. Arif Zulkifli Nasution (Pemerhati Lingkungan). Weblog [online] 20 Maret 2012. Tersedia di:

$<$ http://bangazul.blogspot.com/2012/0 3/model-komunikasi-lingkunganmasyarakat_ $\quad 7720 . \mathrm{html}>$ [Diakses 05/10/2012]. 